\title{
Nova Uredba o visini trošarine na motorne benzine, plinsko ulje i kerozin za pogon
}

\author{
DANIJELA KULIŠ Institut za javne financije
}

Posljednjih nekoliko godina trošarine na naftne derivate postupno su rasle kako bi se dostigla razina minimalno propisanih u Europskoj uniji. Pristupanjem EU-u, uvodi se u sustav oporezivanje $i$ ostalih energenata koji dotad nisu bili oporezovani. I prije posljednje Uredbe o visini trošarine na motorne benzine, plinsko ulje i kerozin za pogon (NN Iog/I3.) visina gotovo svih trošarina bila je usklađena s europskim propisima. Međutim, višim trošarinama nastoje se prikupiti i dodatni porezni prihodi proračuna. Svako povećanje poreza - između ostaloga - utječe i na cijene proizvoda i usluga, potrošnju i životni standard. U nastavku se razmatra utjecaj primjene Uredbe na cijene goriva.

\section{UvOD}

Vlada je 30. kolovoza 2013. donijela Uredbu o visini trošarine na motorne benzine, plinsko ulje i kerozin za pogon (u daljnjem tekstu: Uredba) čime se za ıo lipa po litri povećavaju trošarine za benzine (olovni i bezolovni) te za plinsko ulje i kerozin za pogon, a trošarina na plinsko ulje za grijanje (loživo ulje) povećana je za 8 lipa po litri. U postotnom iznosu, najveće je povećanje trošarine na plinsko ulje za grijanje (23,32\%) što će, s obzirom na dolazeću sezonu grijanja, direktno utjecati na rast troškova života. Trošarina na plinsko ulje i kerozin za pogon povećava se za 3,9\%, na bezolovni benzin $3 \%$, te na olovni najmanje - 2,5\%. Tablica I. pokazuje da su od siječnja do rujna trošarine na motorne benzine povećane za 8-10\%, plinska ulja I3-23\%, a na kerozin za pogon 18,6\%.

Rast je trošarina (ne samo na energente) u posljednje tri godine značajan. Razlozi su bili usklađivanje s minimalnim trošarinama EU-a, potreba prikupljanja poreznih prihoda za pokrivanje rastućih javnih rashoda kao i pritisci zdravstvenih i ekoloških politika.

Svako povećanje trošarine može rezultirati povećanjem cijena oporezivih proizvoda, no u nastavku će se nastojati prikazati koliko najnovije povećanje trošarina na energente utječe i na povećanje maloprodajnih cijena oporezivih proizvoda.

Ministarstvo financija u Prijedlogu Uredbe navodi kako povećanje visine trošarina neće utjecati na maloprodajne cijene (MPC), budući da se za odgovarajući iznos umanjuje premija energetskih 
subjekata. Tako, istodobno s Uredbom, na snagu stupaju i Izmjene Pravilnika o utvrđivanju najviših maloprodajnih cijena naftnih derivata (NN I09/13) u kojima su utvrđene nove visine premija energetskih subjekata.

\section{Tablica I.}

Promjena visine trošarine u razdoblju od I. I .20I3. do 3. 9. 20I3., (u kn/I.ooo l)

\begin{tabular}{|c|c|c|c|c|}
\hline \multirow[t]{2}{*}{ Trošarinski proizvodi } & \multirow{2}{*}{$\begin{array}{c}\text { Uredba, na snazi od } \\
\text { I.1.20I3. }\end{array}$} & \multirow{2}{*}{$\begin{array}{c}\text { Zakon o trošarinama, } \\
\text { na snazi od 1.7.20I3. }\end{array}$} & \multicolumn{2}{|c|}{ Uredba, na snazi od } \\
\hline & & & 23.7.2013. & 3.9.2013 \\
\hline \multicolumn{5}{|c|}{ Motorni benzin - pogonska goriva } \\
\hline olovni & $3.80 \mathrm{I}$ & $3.8 \mathrm{OI}$ & 4.000 & 4.IOO \\
\hline bezolovni & $3.15 \mathrm{I}$ & $3.15 \mathrm{I}$ & 3.360 & 3.460 \\
\hline \multicolumn{5}{|l|}{ Plinsko ulje (dizel) } \\
\hline za pogon & 2.354 & $2.450,50$ & 2.560 & 2.660 \\
\hline za grijanje & 343 & 343 & & 423 \\
\hline \multicolumn{5}{|l|}{ Kerozin - petrolej } \\
\hline za pogon & 2.243 & $2.450,50$ & 2.560 & 2.660 \\
\hline za grijanje & & 1.752 & & \\
\hline
\end{tabular}

Izvor: Narodne novine, I37/I2., 22/I3., 93/I3. i IO9/I3.

\section{PREMIJE ENERGETSKIH SUBJEKATA I UTVRDIVANJE NAJVIŠIH MALOPRODAJNIH GIJENA NAFTNIH DERIVATA}

Pravilnikom kojeg donosi Ministarstvo gospodarstva, utvrđuje se način obračuna, objave i primjene najviših MPC-a naftnih derivata (benzina, dizelskih goriva i plinskih ulja) koje na području RH smiju primijeniti energetski subjekti koji se bave trgovinom naftnim derivatima na veliko i/ili na malo.

Kako bi se razumjela poveznica između trošarina i premija energetskih subjekata i MPC-a, najprije treba pojasniti značenje tih pojmova.

U određivanju najviše cijene naftnih derivata potrebno je pomoću složene formule izračunati cijenu naftnih derivata u koju nisu uključeni trošarina i PDV. Koristi se šest varijabli: (I) srednja dnevna burzovna cijena naftnih derivata u USD/t; (2) srednji dnevni tečaj u HRK/USD koji objavljuje Hrvatska narodna banka s danom objave srednje dnevne burzovne cijene naftnih derivata; (3) broj dnevnih podataka; (4) broj objavljenih srednjih dnevnih burzovnih cijena naftnih derivata unutar obračunskog razdoblja; (5) gustoća naftnog derivata, te (6) premija energetskog subjekta izražena u kunama po litri proizvoda.

Premija energetskog subjekta je naknada za financiranje obveznih zaliha nafte i naftnih derivata, kao i naknada za biogoriva. Visinu ove premije za sve naftne derivate utvrđuje Vlada. Izuzetak su premije za naftne derivate koji se prodaju na benzinskim postajama na autocestama i na morskoj obali za opskrbu plovila (osim za plavi dizel), koje se utvrđuje slobodno na tržištu, te za naftne derivate s dodatkom multifunkcionalnih aditiva, što znači da mogu biti i više od onih određenih Pravilnikom.

\section{Tablica 2.}

Visina premije energetskog subjekta $(\mathrm{u}$ kn/l)

\begin{tabular}{|c|c|c|c|}
\hline Trošarinski proizvodi & 19.12.2012. & $\begin{array}{c}\text { Na snazi od } \\
\text { r.6.20I3. }\end{array}$ & 3.9.20I3. \\
\hline Motorni benzin & 0,76 & 0,76 & 0,66 \\
\hline Plinsko ulje (dizel) & 0,58 & 0,58 & 0,50 \\
\hline Plavi dizel & 0,50 & 0,50 & 0,50 \\
\hline
\end{tabular}

Izvor: Pravilnik o utvrđivanju najviših maloprodajnih cijena naftnih derivata (NN I45/I2., 62/13. i Iog/13.)

Visina premije energetskog subjekta za motorne benzine i dizelsko gorivo eurodizel BS smanjena je novim Pravilnikom za ıo lipa po litri, za plinsko ulje za grijanje za 8 lipa po litri, a za plavi dizel se nije 
mijenjala. Novi iznosi premija koje će se primjenjivati od 3. do 16. rujna 2013. koristiti će se u formuli za izračun najviših cijena naftnih derivata.

\section{MALOPRODAJNE GIJENE NAFTNIH DERIVATA}

Ministarstvo gospodarstva ${ }^{\mathrm{I}}$ objavilo je 2. rujna 2013. najviše razine MPC-a koje se utvrđuju tako da se na najvišu cijenu naftnih derivata izračunatu po prethodno navedenoj formuli dodaju trošarine i PDV. Tijekom obračunskog razdoblja, energetski subjekt dužan je primijeniti MPC jednaku ili nižu od cijene koju je objavilo Ministarstvo. Međutim, ova odredba se ne odnosi na naftne derivate koji se prodaju na benzinskim postajama na autocestama i na morskoj obali za opskrbu plovila. Energetski subjekti su ovlašteni na području RH primjenjivati različite MPG-e za isti naftni derivat i mijenjati ih tijekom obračunskog razdoblja.

U tablici 3 vidljivo je povećanje MPG-a svih kategorija naftnih derivata u 20I3. Nakon 3. rujna najviše će poskupiti benzin super BS IOO (o,3I kn/l), što je za prosječni spremnik goriva od 50 litara poskupljenje od 15,5 kuna.

\section{Tablica 3.}

Najviša razina maloprodajnih cijena naftnih derivata $(u$ kn/l) u 2013.

\begin{tabular}{|c|c|c|c|c|c|c|c|}
\hline Naziv derivata & I.I. & 5.3 & 28.5 & 23.7 . & 20.8 & 3.9. & $\begin{array}{c}\text { Povećanje } \\
\text { 3.9. }\end{array}$ \\
\hline MB super BS 95 & IO,I7 & IO,82 & IO,23 & IO,64 & IO,5I & 10,78 & 0,27 \\
\hline MB super BS 98 & IO,47 & II,I7 & IO,55 & IO,96 & IO,83 & II,I2 & O,I9 \\
\hline MB super BS IOO & IO,69 & $\mathrm{II}, 4 \mathrm{I}$ & IO,76 & II,I7 & II,O4 & II,35 & $\mathrm{O}, 3 \mathrm{I}$ \\
\hline $\begin{array}{l}\text { Dizelsko gorivo EURODIESEL } \\
\text { BS }\end{array}$ & 9,65 & 9,93 & 9,43 & 9,92 & 9,82 & IO,OI & O,I9 \\
\hline Plinsko ulje, LU EL EURO & $6,8 \mathrm{I}$ & 7,04 & 6,58 & 6,75 & 6,69 & 6,87 & O,I8 \\
\hline $\begin{array}{l}\text { Plinsko ulje obojano plavom } \\
\text { bojom EURO }\end{array}$ & $6, \mathrm{I5}$ & 6,66 & $6, \mathrm{I} 6$ & 6,29 & 6,29 & 6,47 & O,I8 \\
\hline $\begin{array}{l}\text { Plinsko ulje obojano plavom } \\
\text { bojom }\end{array}$ & 6,06 & 6,28 & & & & & \\
\hline
\end{tabular}

Napomena: Odabrani su datumi u razmaku od oko 2 mjeseca (2013. je bilo I9 objava).

Izvor: MINGO (2013)

\section{HRVATSKE I MINIMALNE PROPISANE EUROPSKE TROŠARINE}

U članku 2. Uredbe (NN Io9/13) stoji da se Uredbom u pravni poredak RH prenosi Direktiva Vijeća 2003/96/EZ od 27. listopada 2003. o restrukturiranju sustava Zajednice o oporezivanju energenata i električne energije (SL L 283, 3I.IO.2003.). Od stupanja na snagu Zakona o trošarinama (I. siječnja 2010.), visine trošarina na goriva postupno su se povećavale. Od I. srpnja 2013. uvode se i nove trošarine na energente koji se do tada nisu oporezivali (na prirodni plin i električnu energiju). Uspoređujući visinu trošarina $u$ RH (tablica 4) s minimalno propisanim europskim, vidljivo je da je prilagodba visine stopa učinjena, pa su trošarine $\mathrm{u}$ RH čak i premašile minimalno propisane. Međutim, ako je i zadovoljen uvjet minimalnih stopa propisanih Direktivama EU-a, Vlada može prema Zakonu o trošarinama (čl. 6o., toč. 7.) uredbom mijenjati (povećavati) propisane stope trošarina, ovisno o ciljevima i potrebama fiskalne politike (manjak proračunskih prihoda, rast javnih rashoda, rast javnog duga i sl.). Uostalom, i Direktiva vijeća 2003/96/EZ navodi: „Državama članicama treba omogućiti potrebnu fleksibilnost u definiranju i provedbi politike koja odgovara njihovim nacionalnim okolnostima."

\footnotetext{
${ }^{\mathrm{I}}$ MPC naftnih derivata mijenja se svakih I4 dana.
} 
Tablica 4.

Visina trošarina u RH i minimalne trošarine $u$ EU-u (u kn/I.ooo l)

\begin{tabular}{|c|c|c|c|c|}
\hline Trošarinski proizvodi & $\begin{array}{c}\text { Zakon o trošarinama, } \\
\text { na snazi od } \\
\text { I.7.2013. } \\
\end{array}$ & $\begin{array}{c}\text { Uredba, na snazi od } \\
3 \cdot 9.2013 .\end{array}$ & $\begin{array}{c}\text { Minimalna } \\
\mathbf{u} € / \mathbf{I} .0001\end{array}$ & $\begin{array}{l}\text { U trošarina } \\
\text { u kn 1.ooo* } 1\end{array}$ \\
\hline \multicolumn{5}{|c|}{ Motorni benzin - pogonska goriva } \\
\hline olovni & 4.000 & 4.100 & $42 \mathrm{I}$ & 3.158 \\
\hline bezolovni & 3.360 & 3.460 & 359 & 2.693 \\
\hline \multicolumn{5}{|l|}{ Plinsko ulje (dizel) } \\
\hline za pogon & 2.560 & 2.660 & 330 & 2.475 \\
\hline za grijanje & & 423 & $2 \mathrm{I}$ & 158 \\
\hline \multicolumn{5}{|l|}{ Kerozin-petrolej } \\
\hline za pogon & 2.560 & 2.660 & 330 & 2.475 \\
\hline za grijanje & I. 752 & & $\mathrm{O}$ & $\mathrm{O}$ \\
\hline
\end{tabular}

*I $E U R=7,5 \mathrm{kn}$

Izvor: Narodne novine, 22/I3. i 109/13., Council Directive 2003/96/EC.

\section{ZAKLJUČAK}

Svako povećanje poreza najčešće se odražava na cijenu oporezivog proizvoda, osim ako se pri formiranju MPC-a jednako toliko ne promjene i neki drugi elementi u kalkulaciji. Visina premije energetskog subjekta određena Pravilnikom (uz izuzeća, odnosno slobodno utvrđivanje pod određenim uvjetima) korištena pri izračunu cijena naftnih derivata, manje je značajna od ostalih varijabli korištenih za izračun najviše cijene naftnih derivata, na koju najviše utječu cijene na tržištu Mediterana te devizni tečaj. Nakon donošenja Uredbe, maloprodajne cijene goriva porasle su od i8 do 30 lipa po litri, što neće pogoditi samo građane nego i poslovne subjekte, a može uzrokovati poskupljenje i ostalih proizvoda i usluga. Razlozi povećanja trošarina na energente ne mogu se više opravdavati usklađivanjem $\mathrm{s}$ minimalno propisanim europskim trošarinama, nego je ipak razlog $\mathrm{u}$ jednom od glavnih ciljeva oporezivanja - punjenju državnog proračuna.

\section{LITERATURA}

Council Directive 2003/96/EG of 27 October 2003 restructuring the Community framework for the taxation of energy products and electricity. Official Journal of the European Union, L 283/51.

European Commission, 2013. Excise Duty Tables Part II - Energy Products and Electricity. Brussels: European Commission.

MINGO, 2013. Cijene energenata. Zagreb: Ministarstvo gospodarstva RH.

Pravilnik o utvrđivanju najviših maloprodajnih cijena naftnih derivata, NN 145/12, 62/13 i 109/13. Zagreb: Narodne novine.

Uredba o visini trošarine na motorne benzine, plinsko ulje i kerozin za pogon, NN 137/12, 76/13, 93/13, I09/13. Zagreb: Narodne novine.

Zakon o trošarinama, NN 83/o9, 22/13. Zagreb: Narodne novine. 